\title{
Metabolism of Glucotropaeolin from Tropaeolum majus L. (Nasturtium) and the Bioavailability of Benzyl-Isothiocyanates in Growing Pigs
}

\author{
Katrin Stelter ${ }^{1}$, Elke Bloem ${ }^{2}$, Andreas Berk ${ }^{1 *}$, Sven Dänicke1 \\ ${ }^{1}$ Institute of Animal Nutrition, Friedrich-Loeffler-Institute (FLI), Federal Research Institute for Animal Health, \\ Braunschweig, Germany \\ ${ }^{2}$ Institute for Crop and Soil Science, Federal Research Centre for Cultivated Plants (JKI), Braunschweig, \\ Germany \\ Email: andreas.berk@fli.bund.de
}

Received 28 February 2014; revised 3 April 2014; accepted 11 April 2014

Copyright (C) 2014 by authors and Scientific Research Publishing Inc.

This work is licensed under the Creative Commons Attribution International License (CC BY). http://creativecommons.org/licenses/by/4.0/

(c) (i) Open Access

\section{Abstract}

Tropaeolum majus $\mathrm{L}$. is widely known as a medicinal plant in human medicine. It belongs to the Tropaeolaceae which contains mustard oil glycosides like cruciferous plants. In the case of $T$. majus, the intact glucosinolate glucotropaeolin showed no biological activity, but their degradation products, the isothiocyanates, did. The substances are thought to be enriched in the urinary bladder and the lungs, the active sites to develop their antimicrobial effectiveness. In animal nutrition these effects are of interest in sow management and piglet rearing. Therefore, the kinetics of benzyl-isothiocyanat (BITC) in plasma and the excretion with pig urine in response to nasturtium supplementation at different dosing regimens and galenic forms were examined. Four different groups with catheterized pigs were studied. The animals received the T. majus in different dosages $(2.3,6.9$ and $13.4 \mathrm{mg} \mathrm{GTL} / \mathrm{kg} \mathrm{BW}$ ) and different galenic forms (enteric coated tablets, pulverized tablets and powder) admixed to the feed ration as single bolus to the morning feeding. Blood and urine samples were collected within $24 \mathrm{~h}$ after nasturtium intake and analyzed for free BITC. The results indicated that the enteric coating was not effective in animal feeding. The concentration of BITC in tablet fed pigs was lower compared to animals fed powder or pulverized tablets. The bioavailability of the tablets was only $45 \%$ within $24 \mathrm{~h}$ relative to pulverized tablets. Nevertheless, the tablets could have some advantages in terms of the handling, the stability of the active substance and the dosing. Furthermore, it could be shown that all dosages yielded concentrations in urine and plasma, which can be considered to have an antimicrobial effect.

${ }^{*}$ Corresponding author.

How to cite this paper: Stelter, K., et al. (2014) Metabolism of Glucotropaeolin from Tropaeolum majus L. (Nasturtium) and the Bioavailability of Benzyl-Isothiocyanates in Growing Pigs. Advances in Biological Chemistry, 4, 180-190.

http://dx.doi.org/10.4236/abc.2014.42022 


\section{Keywords}

\section{Tropaeolum majus L.; Benzyl-Isothiocyanate; Pig; Urine; Plasma}

\section{Introduction}

Glucosinolates are mainly present in cruciferous plants, but also in Tropaeolaceae such as Tropaeolum majus L. which has been well known for its healing effects since the time of the Incas [1] [2]. Glucosinolates can be found in all plant parts. In the case of T. majus, they enriched leaves, flowers and seeds. Intact glucosinolates show no biological activity, but their degradation products, the isothiocyanates (ITC) which are said to be highly active against a broad range of organisms, do. ITC are released when the plant material is physically damaged by external influences, such as chewing or cutting. This physical damage activates the enzyme myrosinase which hydrolyses the glucosinolates to the ITC [2]-[5]. The wide spectrum of the medicinal activity of T. majus ranges from antimicrobial, antiviral, antifungal to cancer preventing properties [5]-[8]. Hence, in human medicine T. majus is especially applied to diseases of the respiratory and the urinary tract [9]. Additionally, the antiviral activity to influenza infections in humans is of interest [10].

The broad range of effectiveness of $T$. majus is also of interest in animal nutrition, especially as phytogenic alternative to antibiotic growth promoters. Previous investigations in the 1950s with mustard oil of T. majus have shown improving effects on the performance of pigs and poultry [11]. In particular, the healing effect on respiratory diseases, which is a major problem in pig production and causes high economic losses, is of interest [12]. Another problem in modern swine production is lactational insufficiency in sows [13]. High amounts of bacteria in urine and faeces cause the Mastitis-Metritis-Agalactiae-complex (MMA-complex). The active form of glucotropaeolin (GTL), the benzyl-isothiocyanat (BITC), is renally eliminated and therefore excreted with the urine [14], resulting in a decreased bacterial load in the lower urinary tract and the liquid manure [15] and consequently in a reduced risk of coming down with mastitis [16]. Hence, the use of $T$. majus might be a useful tool to improve the health status in pig production.

In various experiments with catheterized fattening pigs the influence of enteric coated tablets and non-capsulated Tropaeolum majus L. at different dosages was examined to clarify if it is necessary to protect ITC by encapsulated tablets in order to increase their concentration in urine, to elucidate a relationship between the GTL-intake and the ITC concentration in blood and urine. Finally, the investigations were used to demonstrate how much dried plant material of $T$. majus could be ingested by the pigs and identify the maximum ITC concentrations that can be found in plasma and urine.

\section{Material and Methods}

\subsection{Animals and Housing}

The experiment was conducted at the Institute of Animal Nutrition, Federal Research Institute for Animal Health, Braunschweig, Germany according to the European Community regulations concerning the protection of experimental animals and the guidelines of the regional council of Oldenburg, Lower Saxony, Germany.

The pigs of the current investigations were divided into four different groups with a total of 26 male castrated pigs, crossbred German Landrace $\times$ Piétrain, with an initial average body weight (BW) of $47.6 \pm 4.0 \mathrm{~kg}$. The pigs were individually housed in floor pens and fed two equal portions (750 g) restrictively for adapting to the feeding regimen applied during the stay in the balance cages. The feed was given in the morning and in the afternoon and mixed with tap water for a wet feeding. Animals were surgically equipped with vena jugularis externa catheters after the adaptation to the balance cages according to Goyarts and Dänicke [17]. Briefly, pigs were pre-medicated intramuscularly with azaperone (Stresnil ${ }^{\circledR}$, Janssen, Animal Health, Neuss, Germany) and ketamine (Ursotamin ${ }^{\circledR}$, Serumwerk Bernburg, Germany) for sedation, with Atropinum sulfuricum $0.5 \mathrm{mg}$ (Eifelfango ${ }^{\circledR}$, Bad Neuenahr-Ahrweiler, Germany) to reduce salivation. Directly after sedation, a deep level of anaesthesia was achieved by inhalation narcosis with isoflurane (1.5\%). Sterile human silicone hoses $(1.57 \times$ $3.18 \mathrm{~mm}$ and $1.98 \times 3.18 \mathrm{~mm}, 1.50 \mathrm{~m}$, Amt Aromando, Düsseldorf) were used as catheters. After the surgery the pigs were replaced into balance cages until the start of the test protocol. The catheters were cleaned twice a day 
using heparinized physiological saline (25.000 IE/5 ml, Braun Melsungen AG) to keep the functionality.

\subsection{Tropaeolum majus L. Batches}

Tropaeolum majus L. 1: Plants were grown in the years 2005-2007 on a field at the experimental station of the Julius Kühn-Institut (JKI) in Braunschweig. Vegetative plant material was harvested from main vegetative growth until flowering by sickle, delivering plant material with a great proportion of leaf material. The plant material was dried in a ventilated oven at $40^{\circ} \mathrm{C}$ until constancy of weight and finely ground $(<0.12 \mathrm{~mm})$ using an ultra-centrifugal mill (RETSCH, ZM-1000, Haan, Germany). The plant material from the different years was thoroughly mixed and provided the raw material for enteric coated tablets produced by Schaper and Brümmer in Salzgitter, Germany. Before the kernel of the tablet was pressed, the plant material was mixed with microcrystalline cellulose, magnesium stearate, polyvinylpyrrolidone and fine-particle silica as additives. 95 mg plant material was pressed into each kernel. These kernels were enteric coated with eudragit, talcum and trietylcitrate and had a final weight of $190 \mathrm{mg}$.

Tropaeolum majus L. 2: Plants were grown in 2011 and 2012 and not used for tablet production. The plants were cultivated and harvested on the experimental plots of the Institute for Plant Cultivation, Schnega, Germany. At the flowering stage, the aerial parts (mainly flowers and leaves) were harvested by manual cutting. Subsequently, the plant material was dried down to a final moisture content of app. $9 \%$ at $40^{\circ} \mathrm{C}$ in tray driers. The dried material was ground with a 4 mm screen using a hammer mill (Joachim Kreyenborg \& Co, type 10, Münster-Kinderhaus, Germany).

\subsection{Dosing Scheme and Experimental Design}

Two days after the surgery of the pigs, pig feed was supplemented with nasturtium on top of a basal diet as a single bolus in the morning feeding according to the plan shown in Table 1. The experimental diets meet the recommendations by the German Society of Nutrition Physiology [18]. The diet contained mainly wheat (379 $\mathrm{g} / \mathrm{kg})$, barley $(350 \mathrm{~g} / \mathrm{kg}$ ) and soy bean meal $(220 \mathrm{~g} / \mathrm{kg})$. The distributions of the pigs in the different groups are also shown in Table 1. In general, the applied dosages of nasturtium were based on the recommendations of the commission E for humans, which describes a daily amount of $130 \mathrm{mg}$ GTL as a suitable dosage for a person of $60 \mathrm{~kg}$ BW (equivalent to $2.17 \mathrm{mg}$ GTL/kg BW) [19]. The applied dosage in the current investigation ranged on average from 2.3 to $13.4 \mathrm{mg}$ GTL/kg BW of the pigs (Table 1).

Nasturtium of Batch 1 was supplemented as tablets (Group 1) and pulverized tablets (Group 2) with an average dosage of $2.3 \mathrm{mg}$ or $2.4 \mathrm{mg}$ GTL/kg BW to investigate the effect of different galenic forms. The pigs of Group 3 also received nasturtium of Batch 1, but only as pulverized tablets in an average dose of $6.9 \mathrm{mg}$ GTL/kg BW.

To investigate the dose response animals of Group 2 and 3 were either fed with pulverized nasturtium of dosage level 1 or 2 . The animals of Group 4 were fed with finely ground nasturtium powder of Batch 2 and an applied amount of GTL which was 4 to 10-fold (8.2 - $22.6 \mathrm{mg}$ GTL $/ \mathrm{kg} \mathrm{BW}$ ) higher than the dosage level of Group 1. The aim of this investigation was to examine the impact of a high GTL level on acceptance by the pigs and BITC excretion under different feeding regimens. Half of the animals $(n=4)$ received the nasturtium in one portion, while the other half $(n=4)$ received the powder evenly distributed over the entire feeding time of approximately $10-15 \mathrm{~min}$. The unequal distribution of the number of pigs fed with powder and tablets was caused by different factors, especially the acceptance of the tablets and the high dosage of nasturtium powder.

Table 1. Distribution of Tropaeolum majus L. as a single bolus in different galenic forms.

\begin{tabular}{cccccc}
\hline Group & Dosage & Form & $\begin{array}{c}\text { Average GTL-Dose } \\
{[\mathrm{mg} / \mathrm{kg} \text { BW] }}\end{array}$ & $\begin{array}{c}\text { Dosage range } \\
{[\mathrm{mg} / \mathrm{kg} \text { BW }]}\end{array}$ & $\mathbf{n}$ \\
\hline 1 & 1 & Tablets & 2.3 & $2.1-2.6$ & 5 \\
2 & 1 & Pulverized tablet & 2.4 & $2.2-3.1$ & 9 \\
3 & 2 & Pulverized tablet & 6.9 & $6.6-7.2$ & 4 \\
4 & 3 & Powder & 13.4 & $8.2-22.6$ & 8 \\
\hline
\end{tabular}




\subsection{Blood and Urine Sampling}

Blood samples (EDTA) were drawn in the morning (control) prior to feeding the nasturtium supplemented meal and 0.25 h, 0.5 h, 0.75 h, 1 h, 1.5 h, 2 h, 3 h, 4 h, 6 h, 8 h, 10 h, 12 h, 24 h after the bolus. The tubes were centrifuged $\left(2000 \times \mathrm{g}\right.$ for $15 \mathrm{~min}, 15^{\circ} \mathrm{C}$, Heraeus Varifuge $\left.{ }^{\circledR} 3.0 \mathrm{R}\right)$ and the plasma was frozen in aliquots $\left(-80^{\circ} \mathrm{C}\right)$ until analysis of BITC. The non-acidified urine samples were collected in an interval of $12 \mathrm{~h}$ until $24 \mathrm{~h}$ after the bolus. The urine was filtered and frozen $\left(-20^{\circ} \mathrm{C}\right)$ prior to analysis.

\subsection{Analyses}

\subsubsection{Nasturtium and Feed}

Representative samples of the diets were collected and analysed for dry matter, crude ash, crude protein ( $\mathrm{N} \times$ 6.25), ether extract (HCl digestion), crude fiber, sugar (Luff-Schoorl) and starch according to the methods of the Association of German Agricultural Analysis and Research Centres [20].

The GTL content of each Batch and galenic form was determined before mixing the T. majus to the feed of the pigs. The determination was performed by HPLC according to the EU official method (ISO 9167-1) for desulfoglucosinolates [21]. The GTL content was calculated by reference to a calibration curve using purified GTL (Calbiochem-Novabiochem 347358). Desulfoglucosinolates were measured by HPLC (Merck Hitachi D6000 Interface, L6200A Intelligent Pump, L4200 UV-VIS Detector, L7200 Autosampler and a column oven which kept the column at $30^{\circ} \mathrm{C}$ ) with UV detection at $229 \mathrm{~nm}$ using acetonitrile (20\%) and water as eluents and a Lichrospher RP-8 column (Merck, Darmstadt, Germany) $(100 \times 4$ mm, $5 \mu \mathrm{m})$ for separation.

\subsubsection{Quantification of Isothiocyanate in Urine and Plasma}

Urine (filtered) and plasma samples were thoroughly mixed before analysis. The content of total ITC in urine and plasma was determined according to the method of Ye et al. [22]. Briefly, a cyclocondensation-assay was prepared with benzene-1, 2-dithiol building a complex with isothiocyanates that can be determined at $365 \mathrm{~nm}$. Blood samples were treated with 6\% Polyetylene glycol (PEG) on ice for 10 min prior to analysis to precipitate the proteins followed by centrifugation for $5 \mathrm{~min}$ at $17,986 \times \mathrm{g}$ and $4^{\circ} \mathrm{C}$. Urine samples were only centrifuged. For the cyclocondensation-assay $400 \mu \mathrm{L}$ of the supernatant (from plasma or urine) was mixed with $400 \mu \mathrm{L}$ potassiumphosphate buffer (100 mmol/L, pH 8.5) and $800 \mu \mathrm{L} \mathrm{1,} 2$ benzenedithiol (20 mmol prepared in acetonitril) and were incubated for $2 \mathrm{~h}$ in a water bath at $65^{\circ} \mathrm{C}$. After incubation the samples were centrifuged at $1466 \times \mathrm{g}$ for $5 \mathrm{~min}$ at $4^{\circ} \mathrm{C}$. The supernatant can be measured directly by HPLC (Merck Hitachi D6000 Interface, L6200A Intelligent Pump, L4200 UV-VIS Detector, L7200 Autosampler and a column oven which kept the column at $25^{\circ} \mathrm{C}$ ) with UV detection at $365 \mathrm{~nm}$. An isocratic eluent consisting of $85 \%$ methanol and $15 \%$ water was used with a flow rate of $0.3 \mathrm{~mL} / \mathrm{min}$. $25 \mu \mathrm{L}$ of the cyclocondensation-assay were injected and for separation a Supelcosil LC-18 HPLC column $(150 \times 2.1 \mathrm{~mm}, 5 \mu \mathrm{m}$, Sigma-Aldrich) was used. The BITC content was calculated by reference to a calibration curve using phenyl isothiocyanate (PITC) as standard (Fluka 78781).

\subsection{Calculations and Statistics}

The data of the urine samples and plasma analysis were evaluated using the GLM procedure of the SAS-software package (SAS Enterprise Guide 4.3). Group was considered as fixed effects in one way analysis of variance (ANOVA). When effects were considered as significant in the F test $(\mathrm{p}<0.05)$, the means were compared using Tukey test. The values in the current paper are shown as means. The non-linear regression model of the application STATISTICA (StatSoft, version 10) was used to fit the data according to Mercer et al. [23], but modified to force the regression through the origin:

$$
\operatorname{ITC}(\mu \mathrm{g} / \mathrm{L})=\frac{R_{\max } \times t^{0}}{\left(K_{0.5}\right)^{0}+t^{0}+t^{2 \times 0} /\left(K_{s}\right)^{0}}
$$

where $R_{\max }$ is the maximum theoretical BITC concentration, o is the apparent kinetic order, $K_{0.5}$ is the time for $1 / 2$ of $R_{\max }$ and $K_{s}$ is the time indicative for the decreasing part of the regression. The estimated parameters were used to calculate the area under the plasma concentration time curve (AUC) numerically by applying the trapezoidal method. The parameter $I_{\max }$, the time corresponding to $R_{\max }$, was calculated as follows: 


$$
I_{\max }=\left(K_{s} \times K_{0.5}\right)^{0.5}
$$

\section{Results}

\subsection{Diet Composition and Feed Intake}

The analysed composition of the diet meets the recommendations of the Society of Nutrition Physiology [18]. The analysis of the dried plant material of T. majus revealed $26.9 \mathrm{mg}$ GTL/g DM for Batch 1 and $10.4 \mathrm{mg}$ GTL/g DM for Batch 2. The GTL content for the tablets were determined to be $2 \mathrm{mg}$ GTL/tablet. All pigs accepted the supplemented T. majus as tablets (Dose level 1) and pulverized tablets (Dose levels 1 and 2) without any problems. The animals dosed with level 3 (Group 4) showed a variation in their acceptance of the nasturtium-containing meal. The administered amount of dried nasturtium was 80 or 160 g per portion, corresponding to 800 and $1600 \mathrm{mg}$ GTL/portion. In both dosages the acceptance by the animals ranged from restrained feed intake to refusal of feed. Consequently, the actual amount of GTL-intake was calculated by backweighing of not accepted feed.

\subsection{Kinetic of Benzyl Isothiocyanate in Plasma}

In general, the free BITC was detected in all plasma samples. The maximum theoretical concentration $\left(R_{\max }\right)$ of the tablet-fed animals was $94.4 \mu \mathrm{g}$ BITC/L and approximately 2.5-fold lower compared to the values of the pigs that received the pulverized tablets at the same dosage $(227.7 \mu \mathrm{g} \mathrm{BITC/L})$. The values of the area under the time curve (AUC) confirmed these data (Table 2). The AUC ranged from 886 to $2027 \mu \mathrm{g}$ BITC/L plasma*h at dosage 1. In general, AUC values in tablet-fed animals were lower than the values of pigs fed with pulverized tablets or powder. Significant differences in the AUC were recognized between animals received dosage level 1 (Group 1 and 2) and dosage level 2 (Group 3) as well as between animals of Group 1 and 4 (p $<0.001$ ). The calculated AUC increased with increasing GTL-intake as well. Therefore, the AUC of animals receiving dosage level 2 and 3 was nearly twice as high as the AUC of animals fed dosage 1 (Table 2). Time-dependent parameters $K_{0.5}, K_{s}$ and $I_{\max }$ showed no significant differences between the groups, galenic forms or the various dosages. In Figure 1 the time-dependent course of BITC concentration in plasma is shown for the different galenic forms. The curve had an exponential increase followed by a slow decline. The curve progression of animals fed dosage 1 was nearly the same for the different galenic forms, tablets and pulverized tablets. Nevertheless, the level of BITC concentration was higher in animals of Group 1 which received the pulverized form of nasturtium. The concentrations at the point in time of $I_{\max }, K_{0.5}, K_{s}$ and after $24 \mathrm{~h}$ (Table 2) reflected the fact that the values of animals fed pulverized tablets tended to be higher than in the tablet supplemented animals ( $p<0.1$, Table 2). With regard to the other dosages the curve resulted a similar progression, but on a higher level. Animals fed Doses 2 and 3 showed higher concentrations of BITC in plasma over the entire experimental period than animals fed Dose 1. While tablet fed animals (Group 1) revealed a $C_{\text {Imax }}$ of $71.77 \mu \mathrm{g} / \mathrm{L}$, animals of Group 4 (powder) received values of $371.09 \mu \mathrm{g} / \mathrm{L}$, which were more than 5 -fold higher. This effect could be also recognized with

Table 2. Estimated kinetic parameters of pigs supplemented with Tropaeolum majus L. as single bolus in different galenic forms and dosages.

\begin{tabular}{|c|c|c|c|c|c|c|c|c|c|c|}
\hline Group & Form & Dosage & $\begin{array}{c}\mathbf{A U C}_{24} \\
{\left[\mu \mathrm{g} / \mathrm{L}^{*} \mathrm{~h}\right]}\end{array}$ & $\boldsymbol{k}_{05}[\mathrm{~h}]$ & $\begin{array}{c}\boldsymbol{R}_{\max } \\
{[\mu \mathrm{g} / \mathrm{L}]}\end{array}$ & $\boldsymbol{k}_{s}[\mathrm{~h}]$ & $\boldsymbol{I}_{\max }[\mathrm{h}]$ & $\begin{array}{c}\boldsymbol{C}_{\mathrm{K} 0.5} \boldsymbol{C}_{\mathrm{Ks}} \\
{[\mu \mathrm{g} / \mathrm{L}]}\end{array}$ & $\begin{array}{c}C_{\operatorname{Imax}} \\
{[\mu \mathrm{g} / \mathrm{L}]}\end{array}$ & $\begin{array}{c}C_{24 h} \\
{[\mu g / L]}\end{array}$ \\
\hline 1 & Tablets & 1 & $886^{\mathrm{c}}$ & 0.53 & $94.4^{\mathrm{b}}$ & 7.07 & 1.73 & $51.51^{\mathrm{b}}$ & $71.77^{\mathrm{b}}$ & $19.94^{\mathrm{b}}$ \\
\hline 2 & Pulverized tablet & 1 & $2027^{\mathrm{bc}}$ & 0.60 & $227.7^{\mathrm{b}}$ & 7.60 & 1.89 & $121.89^{\mathrm{b}}$ & $181.04^{\mathrm{b}}$ & $40.54^{\mathrm{ab}}$ \\
\hline 3 & Pulverized tablet & 2 & $3958^{\mathrm{a}}$ & 0.66 & $421.3^{\mathrm{a}}$ & 5.87 & 1.96 & $250.33^{\mathrm{a}}$ & $403.73^{\mathrm{a}}$ & $83.24^{\mathrm{a}}$ \\
\hline 4 & Powder & 3 & $3720^{\mathrm{ab}}$ & 0.77 & $412.6^{\mathrm{a}}$ & 5.77 & 2.07 & $240.55^{\mathrm{a}}$ & $371.09^{\mathrm{a}}$ & $77.62^{\mathrm{a}}$ \\
\hline PSEM & & & 442 & 0.15 & 46.9 & 1.49 & 0.30 & 26.28 & 40.60 & 11.93 \\
\hline p-value & & & $<0.001$ & 0.639 & $<0.001$ & 0.717 & 0.864 & $<0.001$ & $<0.001$ & 0.003 \\
\hline
\end{tabular}

$\mathrm{AUC}_{24}$, Area under the time curve after $24 \mathrm{~h} ; K_{0.5}$, time for $1 / 2 R_{\max } ; R_{\max }$, the maximum theoretical BITC concentration; $K_{\mathrm{s}}$, time indicative for the decreasing part of $R_{\max } ; C_{\mathrm{K} 0.5}$, BITC concentration to $K_{0.5} ; C_{K S}$, BITC concentration to $K_{S}$. $C_{I \max }$, BITC concentration to $I_{\max } ; C_{24 \mathrm{~h}}$, BITC concentration after $24 \mathrm{~h}$; PSEM, pooled standard error of means. 


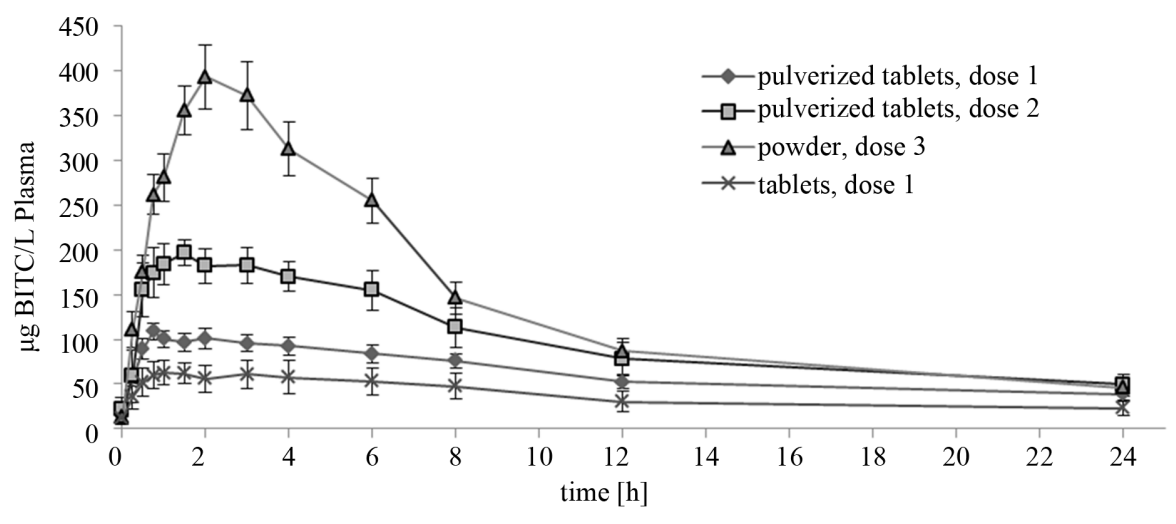

Figure 1. Benzylisothiocyanat concentration in plasma of piglets dosed with Tropaeolum majus L. in different concentrations.

regard to the concentrations corresponding to $K_{0.5}$ and after $24 \mathrm{~h}$. After a period of approximately $1.93 \mathrm{~h}$ the maximum BITC concentration was reached in all experiments independent of the dose and galenic form.

\subsection{Excretion of Glucotropaeolin in Urine}

The analysed metabolite of glucotropaeolin in urine was the free form of BITC as in the plasma analysis. In general, the BITC content in the urine reached its maximum within the first $12 \mathrm{~h}(1-12 \mathrm{~h})$ after intake of $T$. majus independent of the galenic form or dosage. Within the next $12 \mathrm{~h}(13-24 \mathrm{~h})$ the amount of BITC was already 6 times lower independent of dosage and form (Table 3). With regard to the various dosages there were significant differences in the BITC values between the low Doses 1 (Group 1 and 2) and the highest Dose 3 (Group 4) within $24 \mathrm{~h}$. These observation indicated that the relation of BITC in urine and the GTL-intake tended to rise as well $(\mathrm{p}=0.056)$. The amounts ranged from 0.19 (Dose 1, tablets) to $10.22 \mathrm{mg} / \mathrm{animal}$ (Dose 3 ) within the complete 24 hours. No significant differences in the galenic forms (Groups 1 and 2) in animals fed Dosage 1 were recognized. Additionally, there were also no significant differences in the excretion of BITC in response to the different GTL-levels in the feed.

In Group 3, in which the highest dosage of nasturtium was applied, the supplementation of the nasturtium was also examined. Half of the animals $(n=4)$ received the grounded powder as single portion while the other half $(n=4)$ got the nasturtium powder in little portions distributed over the entire feeding time of approximately 10 15 minutes. The results of this administration trial showed that the feeding regimen had a strong impact on ITC excretion with the urine, whereas no effect could be recognized for the transfer into the plasma. The animals which received the nasturtium powder as a single portion excreted only $12.2 \%$ of the BITC compared to those animals with the gradually added nasturtium (2.22 vs. $18.22 \mathrm{mg} /$ animal) within 24 hours (Table 4). Accordingly, the excretion rate of BITC in animals that received the powder as a single portion yielded $0.92 \%$ compared to $9.08 \%$ in the pigs receiving the nasturtium in small portions over the feeding time. Therefore, a nearly 10 -fold higher BITC excretion in urine can be achieved when the nasturtium is administered gradually to the diet.

\section{Discussion}

Glucotropaeolin, the only glucosinolate of Tropaeolum majus L., is relatively non-reactive. Tissue damage releases the enzyme myrosinase which converts the non-reactive form into the active form, the BITC [2] [24] [25]. The bioavailability of this active metabolite is not well established in animals, especially in pigs. Therefore, the current investigation was performed to examine different dosages of GTL to demonstrate the dose response and further to figure out the level of intake. Moreover, different galenic forms were examined: enteric coated tablets were compared with pulverized tablets to reproduce the metabolism of GTL and the passage into the systemic blood circulation as well as in the urinary pathway over an experimental period of 24 hours.

\subsection{Effect of Tropaeolum majus L. on the Plasma Kinetic}

Despite an intensive literature search no investigations comparable to the present animal experiment could be 
Table 3. Isothiocyanate (ITC) excretion in urine of pigs fed with Tropaeolum majus L. as single dose and balance of GTL intake and ITC excretion in relation to the daily urine volume.

\begin{tabular}{|c|c|c|c|c|c|c|c|}
\hline Group & Form & Dosage & $\begin{array}{l}\text { Average GTL intake } \\
\text { [mg/animal] }\end{array}$ & $\begin{array}{c}\mathbf{0}-\mathbf{1 2} \mathbf{h} \\
{[\mathrm{mg} / \text { animal] }}\end{array}$ & $\begin{array}{c}13-24 \text { h } \\
\text { [mg/animal] }\end{array}$ & $\begin{array}{c}\mathbf{0 - 2 4} \mathbf{h} \\
{[\mathrm{mg} / \text { animal] }}\end{array}$ & $\begin{array}{c}\text { Excretion } \\
\text { [\% of intake] }\end{array}$ \\
\hline 1 & Tablets & 1 & 100 & 0.13 & 0.05 & $0.19^{\mathrm{b}}$ & 0.57 \\
\hline 2 & Pulverized tablet & 1 & 113 & 0.20 & 0.10 & $0.30^{\mathrm{b}}$ & 0.78 \\
\hline 3 & Pulverized tablet & 2 & 307 & 1.73 & 0.55 & $2.28^{\mathrm{ab}}$ & 2.23 \\
\hline 4 & Powder & 3 & 668 & 8.78 & 1.44 & $10.22^{\mathrm{a}}$ & 5.00 \\
\hline PSEM & & & & 2.21 & 0.41 & 2.52 & 1.49 \\
\hline p-value & & & & 0.013 & 0.043 & 0.012 & 0.056 \\
\hline
\end{tabular}

Table 4. Isothiocyanate (ITC) excretion in urine and area under the plasma time curve of pigs fed with Tropaeolum majus L. as powder (Dose 3) in different feeding regimens and ITC excretion in relation to the daily urine volume and the GTL intake.

\begin{tabular}{|c|c|c|c|c|c|c|c|c|}
\hline Group & $\begin{array}{l}\text { Form-feeding } \\
\text { regimen }\end{array}$ & Dosage & $\begin{array}{c}\text { Average GTL intake } \\
{[\mathrm{mg} / \mathrm{animal}]}\end{array}$ & $\begin{array}{c}\mathbf{0}-\mathbf{1 2} \mathbf{~ h} \\
\text { [mg/animal] }\end{array}$ & $\begin{array}{c}13 \text { - } 24 \text { h } \\
\text { [mg/animal] }\end{array}$ & $\begin{array}{c}\mathbf{0}-24 \mathbf{h} \\
{[\mathrm{mg} / \text { animal] }}\end{array}$ & $\begin{array}{l}\text { Excretion } \\
\text { [\% of intake] }\end{array}$ & $\begin{array}{l}\mathbf{A U C}_{24} \\
{\left[\mu \mathrm{g} / \mathrm{l}^{*} \mathrm{~h}\right]}\end{array}$ \\
\hline 4 & Powder-all in one & 3 & 726 & 1.93 & 0.29 & 2.22 & 0.92 & 3356 \\
\hline 4 & Powder-gradually & 3 & 610 & 15.63 & 2.58 & 18.22 & 9.08 & 4084 \\
\hline PSEM & & & & 3.13 & 0.65 & 3.47 & 5.77 & 417 \\
\hline $\begin{array}{c}p \text {-value } \\
\text { (form-feeding } \\
\text { regimen) }\end{array}$ & & & & 0.021 & 0.048 & 0.017 & 0.021 & 0.264 \\
\hline
\end{tabular}

found. Some human studies or investigations with rats were conducted with Tropaeolum majus L. or other plants containing mustard oil glucosinolates, but there were no kinetic studies using pigs. In investigations of Brüsewitz et al. [24] rats were administered orally with radioactive labelled cysteine conjugates of benzyl isothiocyanate to examine the excretion of BITC in urine and the kinetic of radioactivity in plasma. The results showed the maximum plasma concentration of radioactivity within $45 \mathrm{~min}$. These results differ from those of the current investigation in which the maximum plasma values were reached within $1.93 \mathrm{~h}$. However, Brüsewitz et $a l$. [24] applied the isothiocyanate directly as substance, while animals in the present investigation were fed with the dried plant material. Interestingly, the same researchers also investigated the application of radioactive labelled cysteine conjugates to dogs and recognized a slower absorption than in rats. The maximum plasma concentration was achieved after 1.5 hours and remained until 6 hours. These results were more comparable to our curve progression of plasma BITC. In consequence, the researchers concluded species-specific, and in addition gender specific, kinetics of the cysteine conjugate of $\left[{ }^{14} \mathrm{C}\right]$ benzyl isothiocyanate. The AUC as determined for male rats was significantly higher than that for female rats. Within the current investigation there was no possibility to make a statement about gender related differences, as only male pigs were used. In a human study of Platz et al. [26] a dosage of $10 \mathrm{mg}$ freeze-dried nasturtium was administered to male and female volunteers to determine metabolites of BITC in plasma and urine. The results showed that the maximum of BITC metabolites in plasma were detected within $1.5 \mathrm{~h}$, which is in accordance to the findings of the present investigation. A further similarity of the current investigation and Platz et al. [26] was the time dependent decrease of BITC in urine within the experimental period of $24 \mathrm{~h}$. The majority of the metabolites were excreted after that time. In all previously published investigations the applied forms of glucosinolates containing material differed from that of the current study. In human studies vegetables in raw or cooked form, like broccoli or garden cress, were used to examine the pharmacokinetics of glucosinolates after ingestion [4] [22]. Brüsewitz et al. [24] used benzyl isothiocyanate and its conjugates in the direct form dissolved in ethanol, water or pyridine by different administrations (orally, intravenously). In the current investigation there were enteric coated tablets, pulverized tablets and nasturtium powder administered orally to the animals with the diet. It was found that glucosinolates were already degraded to a great proportion during chewing of the material [2]. With regard to the ratio of $\mathrm{AUC}_{\text {pulver- }}$ ized tablets and $\mathrm{AUC}_{\text {tablets }}$ it was noticeable that the bioavailability of tablets was only $45 \%$ of that of pulverized 
tablets within 24 hours after ingestion. Nevertheless, the different galenic forms do not lead to significant differences in the analysed BITC concentrations in plasma in animals fed Dose 1. The reason for this effect was the high animal individual variability and the small number of animals. These effects were possibly caused by the feeding behaviour of the pigs. Some of the pigs fed very slowly while others ate very fast or they chewed the feed more extensively. Nevertheless, regarding the time curves of BITC concentration after consuming tablets and pulverized tablets, it was obvious that the GTL of the pulverized form was metabolised faster than the tablets. Consequently, the active substance in pulverized tablets was detected faster in the systemic blood circulation and showed a higher bioavailability compared to enteric coated tablets. Hence, the encapsulation of nasturtium did not lead to a significantly better bioavailability within $24 \mathrm{~h}$.

The blood analysis showed a clear dose response independent of the galenic form. Animals fed the enteric coated tablets corresponding to the lowest GTL dose showed the smallest BITC concentration in plasma at every time point (Table 2), whereas animals administered to Dosages 2 and 3 with a higher application of GTL also revealed higher BITC concentration over the entire investigation.

\subsection{BITC Excretion with Urine}

Benzyl isothiocyanate is absorbed in the gastrointestinal tract and metabolized sequentially by various enzymes like glutathione S-transferase (GST) and $\gamma$-glutamyltranspeptidase ( $\gamma$-GT) to mercapturic acid and finally excreted in urine [24] [27].

In the current investigation a dose dependent excretion of BITC was observed while other degradation products were not monitored. The pigs which received the lowest level of nasturtium also excreted much smaller BITC proportions via urine compared to animals fed the higher dosage. This effect was in accordance with Bollard et al. [28] who administered allyl isothiocyanate (AITC), the ITC of sinigrin, in different ways (intravenous and peros) to rats. They also revealed a dose dependent excretion of thiocyanates. Shapiro et al. [29] recognized a linear correlation between the dosage and the metabolites excreted with the urine as well. The higher the dosage, the higher was the BITC excretion with the urine. Bollard et al. [28] identified metabolites of nearly $80 \%$ of the applied oral dosage of AITC in the urine after 4 days, whereas in the current study only $0.6 \%$ to $9.1 \%$ of the oral dose could be detected in the urine within $24 \mathrm{~h}$. The dosage Bollard et al. [28] applied was comparable to the Dosage 2 (2.4 mg GTL/kg) used in the current investigation. While the pigs of the present study achieved GTL-containing plant material, Bollard et al. [28] administered pure dissolved AITC solution to the rats. Consequently, it can be suggested that the metabolism of the pure substance in rats differed from that of the plant material. Shapiro et al. [29] [30] postulated the important influence of the gastrointestinal microflora on the metabolism of glucosinolates in human. They recognized that the conversion to isothiocyanate was mediated by the microbiota in the gut. These, in turn, could be affected by diet, host genetic factors, gastrointestinal transit time and the enterohepatic circulation [30]. The low recovery rate of BITC in urine in the current investigation can be attributed to the administration of the nasturtium plant material. Bloem et al. [31] demonstrated that fresh plant material from T. majus which was crushed with water lost 96.5\% of GTL within 1.25 min and only traces were left. Therefore, it was expected that with an enteric coated encapsulation of the plant material, higher proportions of BITC could be yielded in urine.

However, it was not possible to prevent the destruction of the tablets by chewing of the pigs which caused the early degradation of the GTL in the mouth and an obvious complete loss prior to absorption. The release of isothiocyanate is dependent on mechanical factors like chewing, damage of the plant tissue [2] [32], moistening of the feed and of other factors like the pH value [33] [34]. Nasturtium supplemented feed of Doses 1 and 2 was consumed very quickly and chewing was not very distinctive, while animals fed Dose 3 were restrained in their feeding and ate very slowly. The feeding behaviour notably influenced the concentration in urine. Feeding the nasturtium in little portions over the feeding time caused a 10-fold higher BITC excretion via the urine compared to animals administered the nasturtium as a single portion. Possibly the longer soaking of the plant material of nasturtium in the water-mixed feed or the slower feed intake were responsible for the lower excretion rate. It can be assumed that the pigs ingested BITC and metabolites of GTL as soon as the feed was soaked for a longer time period.

A further effect for the low recovery rate in the urine could also be due to a release of BITC with the lungs or an excretion of non-absorbed BITC with the faeces. BITC can also be eliminated by pulmonary exhalation [1] which is the rationale of the action of T. majus against infections of the respiratory tract. Brüsewitz et al. [24] 
detected $0.4 \%$ of the administered radioactive labelled cysteine conjugate of BITC in the expired air of rats while Bollard et al. [28] recovered 10\% - 18\% of the applied proportion in faeces and in the expired air. In the current study it was not possible to estimate the release of BITC via other pathways, but the data indicated that the feeding regimen influenced the recovery rate conspicuously.

Nevertheless, the analysed concentrations of BITC in the urine, independent of the dosage and the galenic form of T. majus, were sufficiently high to yield a bactericide or bacteriostatic effect. Concentrations of benzyl mustard oil of 0.5 to $50 \mu \mathrm{g} / \mathrm{mL}$ were shown to have a high antimicrobial effectiveness [1]. The values of the current investigation ranged from 0.19 to $10.22 \mathrm{mg}$ BITC/animal with an average amount of urine of $764 \pm 345$ $\mathrm{g}$ within $24 \mathrm{~h}$. Therefore, pathogenic bacteria in the gastrointestinal tract of the pigs and in the liquid manure could probably be effectively inhibited by the supplemented nasturtium independent of the galenic form, because of the high concentration of active BITC in the urine.

\section{Conclusion}

The current investigation in which pigs were supplemented with Tropaeolum majus L. in different dosages and galenic forms showed that the encapsulation of the plant material was not necessary to increase BITC concentrations in the urine. The active substance reached the systemic blood circulation faster when administered in pulverized form or as nasturtium powder. The bioavailability of the tablets was only $45 \%$ within $24 \mathrm{~h}$ relative to the pulverized tablets. Therefore, the expensive encapsulation is not necessary in animal feeding. Nevertheless, encapsulated tablets could have some benefits in practice. On one hand, the defined dosage could be more easily administered to the animals, and on the other hand the encapsulation ensured a longer stability of the active substance compared to dried plant material. Due to the results of the BITC in urine it can concluded that the feeding regime has a strong influence on the urinary excretion of BITC, despite the fact of the ingested amount of nasturtium. Even with the intake of the lowest dosage of GTL, independent of the galenic form, the BITC concentration in the urine was high enough to potentially reduce the bacterial load in the lower urinary tract of pigs. To sum up, even small amounts of nasturtium powder are able to inhibit pathogen bacteria in urine and further improve the health status of pigs, especially in sow management and piglet rearing.

\section{Acknowledgements}

This work was supported by the Fachagentur für Nachwachsende Rohstoffe (FNR), Gülzow, Germany.

\section{References}

[1] (1985) Anonymous, Scientific Elaboration of Tropaeolum Maius (majus) l. (“in German”). Kooperation Phytopharmaka-Working Group Efficiancy Treatment of Scientific Data Concerning Efficacy, Safety, Quality, Toxicology and Clinic, Bonn, Germany.

[2] Fahey, J.W., Zalcmann, A.T. and Talalay, P. (2001) The Chemical Diversity and Distribution of Glucosinolates and Isothiocyanates among Plants. Phytochemistry, 56, 5-51. http://dx.doi.org/10.1016/S0031-9422(00)00316-2

[3] Vermeulen, M., van den Berg, R., Freidig, A.P., van Bladeren, P.J. and Vaes, W.H.J. (2006) Association between Consumption of Cruciferous Vegetables and Condiments and Excretion in Urine of Isothiocyanate Mercapturic Acids. Journal of Agricultural and Food Chemistry, 54, 5350-5358. http://dx.doi.org/10.1021/jf060723n

[4] Kumar, A. and Sabbioni, G. (2010) New Biomarkers for Monitoring the Levels of Isothiocyanates in Humans. Chemical Research in Toxicology, 23, 756-765. http://dx.doi.org/10.1021/tx900393t

[5] Pintão, A.M., Pais, M.S., Coley, H., Kelland, L.R. and Judson, I.R. (1995) In Vitro and in Vivo Antitumor Activity of Benzyl Isothiocyanate: A Natural Product from Tropaeolum Majus. Planta Medica, 61, 233-236. http://dx.doi.org/10.1055/s-2006-958062

[6] Shapiro, T.A., Fahey, J.W., Wade, K.L., Stephenson, K.K. and Talalay, P. (2001) Chemoprotective Glucosinolates and Isothiocyanates of Broccoli Sprouts. Cancer Epidemiology Biomarkers \& Prevention, 10, 501-508.

[7] Bazylko, A., Granica, S., Filipek, A., Piwowarski, J., Stefańska, J., Osińska, E. and Kiss, A.K. (2013) Comparison of Antioxidant, Anti-Inflammatory, Antimicrobial Activity and Chemical Composition of Aqueous and Hydroethanolic Extracts of the Herb of Tropaeolum Majus l. Industrial Crops and Products, 50, 88-94. http://dx.doi.org/10.1016/j.indcrop.2013.07.003

[8] Halbeisen, T. (1954) Untersuchungen über die antibiotischen Wirkstoffe von Tropaeolum majus (Kapuzinerkresse). Naturwissenschaften, 41, 378-379. http://dx.doi.org/10.1007/BF00684067 
[9] Gasparotto Junior, A., Prando, T.B.L., Leme, T.D.S.V., Gasparotto, F.M., Lourenço, E.L.B., Rattmann, Y.D., Da Silva-Santos, J.E., Kassuya, C.A.L. and Marques, M.C.A. (2012) Mechanisms Underlying the Diuretic Effects of Tropaeolum Majus l. Extracts and Its Main Component Isoquercitrin. Journal of Ethnopharmacology, 141, 501-509. http://dx.doi.org/10.1016/j.jep.2012.03.018

[10] Winter, A. and Rings-Willeke, L. (1958) Untersuchungen über den Einfluss von Senfölen auf die Vermehrung des Influenza-Virus im exembryonierten Hühnerei. Archiv für Mikrobiologie, 31, 311-318. http://dx.doi.org/10.1007/BF00409992

[11] Boeger, O., Westerhoff, W. and Winter, A.G. (1955) Untersuchungen über Antibiotika aus höheren Pflanzen. Schweinemastversuche mit den antimikrobischen Wirkstoffen der Kapuzinerkresse. Naturwissenschaften, 42, 464-464. http://dx.doi.org/10.1007/BF00634082

[12] Reeth, K.V. and Nauwynck, H. (2000) Proinflammatory Cytokines and Viral Respiratory Disease in Pigs. Veterinary Research, 31, 187-213. http://dx.doi.org/10.1051/vetres:2000113

[13] Martineau, G.P., Smith, B.B. and Doize, B. (1992) Pathogenesis, Prevention, and Treatment of Lactational Insufficiency in Sows. Veterinary Clinics of North America: Food Animal Practice, 8, 661-684.

[14] Winter, A.G. (1954) Hemmstoffkonzentrationen im urin nach aufnahme von salat bzw. Wirkstoffanreicherungen (tromalyt) der kapuzinerkresse. Naturwissenschaften, 41, 379-380. http://dx.doi.org/10.1007/BF00684068

[15] Bergmann, M., Lipsky, H. and Glawogger, F. (1966) Ein Antibiotikum aus der Kapuzinerkresse bei Harnwegsinfektionen. Medizinische Klinik, 61, 1469-1472.

[16] Gerjets, I. and Kemper, N. (2009) Coliform Mastitis in Sows: A Review. Journal of Swine Health and Production, 17, 97-105.

[17] Goyarts, T. and Dänicke, S. (2006) Bioavailability of the Fusarium Toxin Deoxynivalenol (DON) from Naturally Contaminated Wheat for the Pig. Toxicology Letters, 163, 171-182. http://dx.doi.org/10.1016/j.toxlet.2005.10.007

[18] GfE (2006) Society of Nutrition Physiology, Recommendations for the Supply of Energy and Nutrients to Pigs. Energy and Nutrients Requirements for Livestock. DLG-Verlags GmbH, Committee for Requirement Standards of the Society of Nutrition Physiology, Frankfurt am Main.

[19] Blumenthal, M., Busse, W.R., Goldberg, A., Gruenwald, J., Hall, T., Riggins, C.W. and Rister, R.S. (1998) The Complete German Commission E Monographs: Therapeutic Guide to Herbal Medicines. American Botanical Council, Austin.

[20] Naumann, C. and Bassler, R. (1993) Die chemische Untersuchung von Futtermitteln. VDLUFA-Verlag.

[21] Anonymous (1990) Bestimmung des Glucosinolatgehaltes von Oelsaaten durch HPLC. EU Methode Nr. L170/28.

[22] Ye, L., Dinkova-Kostova, A.T., Wade, K.L., Zhang, Y., Shapiro, T.A. and Talalay, P. (2002) Quantitative Determination of Dithiocarbamates in Human Plasma, Serum, Erythrocytes and Urine: Pharmacokinetics of Broccoli Sprout Isothiocyanates in Humans. Clinica Chimica Acta, 316, 43-53. http://dx.doi.org/10.1016/S0009-8981(01)00727-6

[23] Mercer, L.P., May, H.E. and Dodds, S.J. (1989) The Determination of Nutritional Requirements in Rats: Mathematical Modeling of Sigmoidal, Inhibited Nutrient-Response Curves. Journal of Nutrition, 119, 1465-1471.

[24] Brüsewitz, G., Cameron, B.D., Chasseaud, L.F., Gorler, K., Hawkins, D.R., Koch, H. and Mennike, W.H. (1977) The Metabolism of Benzyl Isothiocyanate and Its Cysteine Conjugate. Biochemical Journal, 162, 99-107.

[25] Lamy, E., Scholtes, C., Herz, C. and Mersch-Sundermann, V. (2011) Pharmacokinetics and Pharmacodynamics of Isothiocyanates. Drug Metabolism Reviews, 43, 387-407. http://dx.doi.org/10.3109/03602532.2011.569551

[26] Platz, S., Kuhn, C., Schiess, S., Schreiner, M., Mewis, I., Kemper, M., Pfeiffer, A. and Rohn, S. (2013) Determination of Benzyl Isothiocyanate Metabolites in Human Plasma and Urine by LC-ESI-MS/MS after Ingestion of Nasturtium (Tropaeolum majus L.). Analytical and Bioanalytical Chemistry, 405, 7427-7436. http://dx.doi.org/10.1007/s00216-013-7176-7

[27] Zhang, Y.S., Kolm, R.H., Mannervik, B. and Talalay, P. (1995) Reversible Conjugation of Isothiocyanates with Glutathione Catalyzed by Human Glutathione Transferases. Biochemical and Biophysical Research Communications, 206, 748-755. http://dx.doi.org/10.1006/bbrc.1995.1106

[28] Bollard, M., Stribbling, S., Mitchell, S. and Caldwell, J. (1997) The Disposition of Allyl Isothiocyanate in the Rat and Mouse. Food and Chemical Toxicology, 35, 933-943. http://dx.doi.org/10.1016/S0278-6915(97)00103-8

[29] Shapiro, T.A., Fahey, J.W., Wade, K.L., Stephenson, K.K. and Talalay, P. (1998) Human Metabolism and Excretion of Cancer Chemoprotective Glucosinolates and Isothiocyanates of Cruciferous Vegetables. Cancer Epidemiology Biomarkers \& Prevention, 7, 1091-1100.

[30] Shapiro, T.A., Fahey, J.W., Dinkova-Kostova, A.T., Holtzclaw, W.D., Stephenson, K.K., Wade, K.L., Ye, L. and Talalay, P. (2006) Safety, Tolerance, and Metabolism of Broccoli Sprout Glucosinolates and Isothiocyanates: A Clinical Phase I Study. Nutrition and Cancer, 55, 53-62. http://dx.doi.org/10.1207/s15327914nc5501_7

[31] Bloem, E., Haneklaus, S. and Schnug, E. (2007) Comparative Effects of Sulfur and Nitrogen Fertilization and Post- 
Harvest Processing Parameters on the Glucotropaeolin Content of Tropaeolum majus L. Journal of the Science of Food and Agriculture, 87, 1576-1585. http://dx.doi.org/10.1002/jsfa.2895

[32] Bloem, E., Berk, A., Haneklaus, S., Selmar, D. and Schnug, E. (2008) Influence of Tropaeolum Majus Supplements on Growth and Antimicrobial Capacity of Glucotropaeolin in Piglets. Agriculture and Forestry Research, 58, $203-210$.

[33] Gil, V. and MacLeod, A.J. (1980) The Effects of pH on Glucosinolate Degradation by a Thioglucoside Glucohydrolase Preparation. Phytochemistry, 19, 2547-2551. http://dx.doi.org/10.1016/S0031-9422(00)83916-3

[34] Halkier, B.A. and Gershenzon, J. (2006) Biology and Biochemistry of Glucosinolates. Annual Review of Plant Biology, 57, 303-333. http://dx.doi.org/10.1146/annurev.arplant.57.032905.105228 